\title{
ENGLISH-MAJORED STUDENTS' MOTIVATION IN ENGLISH LANGUAGE LEARNING AND THEIR USE OF READING STRATEGIES: RESEARCH PERSPECTIVES
}

\author{
Tran Quoc Thao ${ }^{1}$, Nguyen Hoang Chau Long ${ }^{2}$ \\ 1. Ho Chi Minh City University of Technology (HUTECH) \\ 475A Dien Bien Phu, Ward 25, Binh Thanh, Ho Chi Minh City, Vietnam \\ 2. Phan Ngoc Hien Gifted High School \\ 74 Phan Dinh Phung, Ward 2, Ca Mau City, Ca Mau, Vietnam
}

Received 2 August 2020

Revised 12 October 2020; Accepted 23 January 2021

\begin{abstract}
Reading plays a vital role in improving second/foreign language learning as it can encourage the development of autonomous learners. Furthermore, ESL/EFL learners' use of reading strategies can be affected by their learning motivation, which can result in the high or low frequent use of reading strategies in reading comprehension. The present study, therefore, investigated the motivation in English language learning and the use of reading strategies among English-majored freshmen at a university in Bac Lieu province, Vietnam. A questionnaire was used to collect data from 180 English-majored freshmen, six of whom took part in semistructured interviews. The results showed that participants had a high level of motivation in English language learning, and their metacognitive strategies worked better with their reading comprehension than their cognitive and social/affective strategies. The study further unraveled that the more participants were motivated in English language learning, the more they employed metacognitive and cognitive strategies in reading comprehension.
\end{abstract}

Key words: English language learning, English-majored students, motivation, reading comprehension, cognitive/metacognitive reading strategies

\section{Introduction}

Reading is considered to be the most important of the four skills, particularly in English as a second or a foreign language (Anderson, 2003), and it is the most essential skill and has a great impact on the EFL students' language development, especially for the young learners among four language skills (Al-Issa, 2006). Additionally, reading is the most important skill to master in order to ensure success in learning, and it has been considered as an interactive process with many different levels that readers can build a meaningful representation of text by using their background knowledge (Mart, 2012; Tran \& Duong, 2018). Nevertheless, students need learning motivation to read. Yunus and Abdullah (2011) have pinpointed that motivation plays an important role in language learning, and students need to initiate the steps towards language learning. Pardo (2004) asserts that students' learning motivation is really important for teachers to

\footnotetext{
* Corresponding author. Tel.: 84-989637678

Email: tq.thao@hutech.edu.vn
}

encourage them to improve their reading skills. Furthermore, it is supposed that reading strategies can be an influence on students' reading comprehension. Students' use for reading strategies has a vital role in boosting their reading comprehension (Anderson, 2003; Hong-Nam \& Leavell, 2006; Wharton, 2000).

In the context of Vietnam, English as a foreign language is learned as the main and compulsory subject at different levels of education. The reading skill is one of the most common ones which is highly focused in English teaching and learning curricula; nonetheless, reading does not always interest students (Tran \& Duong, 2018; Tran \& Tran, 2018). Regarding English-majored students at a higher institution in Bac Lieu Province, reading is one of the English language skills that they have to study. Some are observed to be highly interested in this subject, while others seem reluctant to read, and they just read when being assigned reading tasks. The picture of how much English-majored students at a higher institution in Bac Lieu Province are motivated in English language learning and the extent to which they employ reading strategies is still 
unclear. This study, therefore, aims at exploring English-majored students' motivation in English language learning and their use of reading strategies at the context of a university in Bac Lieu Province. The research questions of this study are formed as follows:

1. What is English-majored students' level of motivation in English language learning at a university in Bac Lieu?

2. How are the reading strategies used by English-majored students at a university in Bac Lieu?

3. What is the relationship between Englishmajored students' motivation in English language learning and their use of reading strategies?

\section{Literature Review}

Motivation in language learning is understood as the combination of effort that is not only the desire to achieve the goal of learning the language but also favorable attitudes toward learning the language (Gardner, 1985). Within this definition, motivation is described as goal-directed behaviors; the students set goals before starting to read is also a way to learn the language. What is more, motivation in learning language is a state of cognitive and emotional arousal, which contributes to be aware of decision to carry out and gives rise to a stage of maintained intellectual and/or mental effort so as to obtain a previously set goal or goals (William \& Burden, 1997). Additionally, motivation is the progress to which learners make choices about reaching goals to pursue and the effort they will devote to that pursuit (Brown, 2001). Therefore, motivation is considered as an indispensable role for successful language learning and may influence strongly on the way language learning use learning strategies (Dao, 2010), and a fully motivated student is a person who is ready or even eager to invest effort in learning activities and knowledge in advance (Ur, 1996). The motivation in learning language has been divided into two kinds: instrumental motivation and integrative motivation (Chambers, 1999; Crookes \& Schmidt, 1991; Finegan, 1999). Integrative motivation is characterized by a positive attitude towards the speakers and culture of the target language, as long as instrumental motivation is characterized by learning the language for practical purposes, such as gaining employment or passing a test (Ellis, 1994). That means if a person wants to learn a language only for their own purpose like getting a job or fulfilling an academic requirement, she or he will be affected by instrumental motivation. On the other hand, instrumental motivation refers to the motivation that acquire a language as the means of setting goals such as raising a career or job or reading academic texts while integrative motivation has to deal with being accepted by another community or integrating oneself within a culture to become a part of that society (Chambers, 1999).

The definition "reading comprehension" has been investigated under numerous perspectives by different linguists, educators and second language researchers; however, each definition can be only the reflection of its author's particular view of the reading process. Reading is regarded as a passive decoding process where "meaning is embodied in the text and the reader can extract the meaning from the print if he understands it letter by letter and word by word" (Goodman, 1988, p. 43). In addition, reading is considered as "a decoding process of reconstructing the author's intended meaning via recognizing printed letters and words, and building up a meaning for a text from the smallest textual units at the bottom, including letters and words, to larger and larger units at the top, such as phrases, clauses and intersectional linkages" (ibid., p. 44). In another aspect, reading is best described as "an understanding between the author and the reader. Reading is much more than just pronouncing words correctly or simply knowing what the author intends; it is the process whereby the printed page stimulates ideas, experiences and responses that are unique to an individual" (Richards \& Thomas, 1987, p. 9). Deriving from above-discussed definitions, reading comprehension is a means of language acquisition, of communication, and of sharing information and ideas. It is a complex interaction between the text and the reader which is shaped by the reader's prior knowledge, experiences, attitude, and language community which is culturally and socially situated. The reading process requires continuous practices, development, and refinement. 
Reading strategies can be divided into three groups, namely metacognitive strategies, cognitive strategies and social/ affective strategies. Metacognitive strategies are "higher order executive skills that may entail planning or, monitoring, or evaluating the success of a learning activity" (O’Malley \& Chamot, 1990, p. 44). They are used for (1) planning: previewing the main ideas and concepts of the material to be learnt, often by skimming the text for the organizing principle; (2) monitoring: checking one's comprehension during listening or reading checking the accuracy and/ or appropriateness of one's oral or written production while it is taking place; (3) and selfevaluating: checking the outcomes of one's own language against a standard after it has been completed. Cognitive strategies are "more directly related to individual learning tasks and entail direct manipulation or transformation of the learning material" (ibid., p. 8). Typical strategies that have been discussed in the cognitive category for reading comprehension are (1) repetition: imitating a language model, including overt practice and silent rehearsal; (2) grouping: classifying words, terminology or concepts according to the attributes or meaning; (3) deduction: applying rules to understand or produce the second language making up rules based on language analysis; (4) imagery: using visual images (either mental or actual) to understand or remember new information; (5) elaboration: relating new information to prior knowledge, relating different parts of new information to each other, or making meaningful personal associations with the new information; (6) transfer: using previous linguistic knowledge or prior skills to assist comprehension or production; (7) inferencing: using available information to guess meaning of new items, predict outcomes or fill in missing information; (8) summarizing: making a mental, oral or written summary of new information gained through listening and reading. Social/affective strategies are referred to as "a broad grouping that involves either interaction with another person or ideational control over affect" (ibid., p. 45). The social/ affective strategies and their definitions are for (1) questioning for clarification: eliciting from a teacher or peer additional explanations rephrasing, examples or verification; (2) cooperation: working together with one or more peers to solve a problem, pool information, check a learning task, model a language activity, or get feedback on oral or written performance; (3) self-talk: reducing anxiety by using mental techniques that make one feel competent to do the learning task.

Prior studies have been conducted to explore the use of reading strategies. Sheorey and Mokhtari (2001) examined differences in the metacognitive and perceived use of reading strategies among 105 US and ESL university students in the US. The findings showed that both groups of participants had a high level of various reading strategies awareness. Additionally, participants who had high reading abilities used cognitive and metacognitive reading strategies more than those with low reading abilities. Cogmen and Saracaloglu (2009) investigated the use of reading strategies by college students. The sample included 320 students from a college in Turkey who participated in answering the reading strategies questionnaire. The results show that students often used reading strategies in reading academic materials. Guo and Zhang (2020) trained 37 students how to use cognitive and metacognitive reading strategies in EFL reading classes. The results revealed that participants had a high level of motivation in English language learning and tended to employ more cognitive and metacognitive reading strategies. In Vietnam, Ngo (2015) investigated the motivation in English language learning of tertiary students. There were 422 participants (180 non-English majored students; 242 English-majored students) taking part in this study. It was found out that participants had three types of motivation: personal/professional development motivation, intrinsic motivation, obligation/avoidance motivation, and their personal/professional development motivation was the highest level. Nguyen (2019) examined the motivation in English language learning of 371 first and second-year students of Vietnam National University, Hanoi. The findings indicated that participants were highly motivated in English language learning, and their level of motivation in English language learning was affected by their school year and parental English ability. In brief, different studies have been conducted to explore different aspects of motivation in English language learning and reading strategies. Nevertheless, the relationship between the motivation in English language learning and the use of reading strategies has not been much 
explored in the EFL context of Vietnam; therefore, this study endeavors to find out the English-majored students' motivation in English language learning and their use of reading strategies as well as the relationship between the two research variables.

\section{Methodology}

\subsection{Research context and participants}

This study was conducted at a university in Bac Lieu province, Vietnam. Students had to learn 8 courses of reading from Reading 1 to Reading 8 . For each semester, students had to learn 1 reading subject in 30 periods ( 2 periods

Table 1

Participants' General Information

\begin{tabular}{|c|c|c|c|c|}
\hline \multirow{2}{*}{ No } & \multirow{2}{*}{ Information } & & \multicolumn{2}{|c|}{$\mathbf{N}=\mathbf{1 8 0}$} \\
\hline & & & Frequency & Percentage \\
\hline \multirow[t]{2}{*}{1} & Gender & male & 60 & 33.3 \\
\hline & & female & 120 & 66.7 \\
\hline \multirow[t]{4}{*}{2} & Years of learning English & less than 5 years & 16 & 8.9 \\
\hline & & $5-7$ years & 44 & 24.4 \\
\hline & & $7-9$ years & 98 & 54.4 \\
\hline & & more than 10 years & 22 & 12.3 \\
\hline \multirow[t]{4}{*}{3} & Hours of self-studying English in a day & less than 1 hour & 118 & 65.6 \\
\hline & & 1-3 hours & 41 & 22.8 \\
\hline & & 3-5 hours & 13 & 7.2 \\
\hline & & more than 5 hours & 8 & 4.4 \\
\hline \multirow[t]{4}{*}{4} & Hours of practicing reading English in a day & less than 1 hour & 153 & 85 \\
\hline & & 1-3 hours & 13 & 7.2 \\
\hline & & 3-5 hours & 6 & 3.3 \\
\hline & & more than 5 hours & 8 & 4.5 \\
\hline
\end{tabular}

\subsection{Research Instrument}

This study employed a questionnaire and semi-structured interview to collect data. The questionnaire consists of two parts: part I seeks for participant's personal information and part II includes 40 items divided into two groups: motivation (20 items) adapted from Vallerand et al.'s (1992) study and reading strategies (25 items) adapted from O'Malley and Chamot's (1990) study. was used to items of reading strategies. The motivation has two categories: instrument (11 items) and integrative (9 items), which were designed with a five-point Likert scale (strongly disagree to strongly disagree). The items of reading strategies fall into three categories: metacognitive strategies (items 3,8 , $12,18,5,21,6,20,9,1,4,16$ and 9), cognitive strategies (items 7, 15, 13, 2, 11, 14, 17 and 10) and social/affective strategies (items 22, 23, 24, a week), and they had to read a variety of materials and do different reading exercises.

Participants who were purposively sampled were 180 English-majored students (aged from 18 to 19). They were first-year students consisting of 120 females (66.7\%) and 60 males $(33.3 \%)$ as shown in Table 1. As seen from the table, $16(8.9 \%)$ participants have learned English less than five years, 44 (24.4\%) participants having learned English from five to seven years, 98 (54.4\%) participants having learned English from seven to nine years, and $22(12.3 \%)$ participants having learned English over ten years. Among 180 participants, only six students agreed to take part in interviews. and 25), which were designed with a five-point Likert scale from never to always. The semistructured interview includes four main questions aiming to get an in-depth information of motivation and reading strategies. The questionnaire and interview questions were double-checked and translated into respondents' mother tongue so that respondents did not face any language difficulty in understanding and answering the questions.

\subsection{Procedures for data collection and data analysis}

With respect to data collection, the questionnaire and interview had been piloted before they were used in the main study. Two hundred copies of the questionnaire were administered in person to students. It took students 15 minutes to complete the questionnaire. However, 180 copies 
were returned. After the preliminary analysis of questionnaires, the interviews took place one-onone. Each interview lasted around 15 minutes. All interviews were recorded for later analysis.

Regarding data analysis, the quantitative data were processed by the SPSS version 20 in terms of descriptive statistics. The meaning of the interval mean scores is interpreted as 11.80: Strongly disagree/Very low/Never; 1.812.60: Disagree/Low/Seldom; 2.61-3.40: Neutral/Average/Sometimes; $3.41-4.20$ : Agree/High/Usually; and 4.21-5.00: Strongly agree/Very high/Always. The qualitative data were analyzed using the content analysis approach. The interviewees were coded as S1, S2 to S6.

\section{Results and discussion}

\subsection{Results}

\subsubsection{English-majored students' level of motivation}

As shown in Table 2, the mean score of integrative motivation $(\mathrm{M}=3.62, \mathrm{SD}=.85)$ is higher than that of instrument motivation $(\mathrm{M}=3.51, \mathrm{SD}=.72)$. This means that participants had a high level of motivation. To put it another way, English majored students were highly motivated in English language learning.

\section{Table 2}

English-Majored Students' Level of Motivation

\begin{tabular}{lll}
\hline & \multicolumn{2}{l}{$\mathbf{N}=\mathbf{1 8 0}$} \\
\cline { 2 - 3 } & $\mathbf{M}$ & $\mathbf{S D}$ \\
\hline Instrument & 3.51 & .85 \\
Integrative & 3.62 & .72 \\
\hline
\end{tabular}

Note: N: sample; M: mean; SD: standard deviation
The results in Table 3 reveal that the participants strongly agreed that "English is useful to [them] in [their] future profession" (item A5: $\mathrm{M}=4.49, \mathrm{SD}=.67$ ), and they agreed that "being proficient in English can lead to success and achievements in life like higher salary, promotion, and position" (item A17: $\mathrm{M}=3.69, \quad \mathrm{SD}=.51$ ), "studying English is important to [them] because it makes [them] knowledgeable and skillful person which will help [them] to have a better future (item A14: $\mathrm{M}=3.67, \mathrm{SD}=.70$ ), "other people respect [them] more if [they] know English" (item A15: $\mathrm{M}=3.65, \mathrm{SD}=.67$ ), "thanks to English [they] can broaden [their] cultural horizon" (item A8: $\mathrm{M}=3.57, \mathrm{SD}=.60$ ), "knowing English, [they] can read literary works in the original" (item A10: $\mathrm{M}=3.56, \mathrm{SD}=.89$ ) and "English enables [them] to communicate with many people" (item A1: $\mathrm{M}=3.36, \mathrm{SD}=.34$ ). On the other hand, the participants were in agreement with statements, "English helps [them] to be openminded and sociable" (item A3: $\mathrm{M}=3.23$, $\mathrm{SD}=.78)$, "[they] often use English to talk to foreigners" (item $\mathrm{A} 4: \mathrm{M}=3.24, \mathrm{SD}=.88$ ), "knowing English, [they] can read foreign magazines" (item A2: $\mathrm{M}=3.06, \mathrm{SD}=.92$ ), and "sometimes [they] translate English books or instructions on foreign-made machines" (item A11: $\mathrm{M}=3.06, \mathrm{SD}=.73$ ).

Table 3

English-Majored Students' Level of Motivation in Terms of Instrument Motivation

\begin{tabular}{llccc}
\hline \multirow{2}{*}{ No } & \multicolumn{1}{c}{ Statement } & \multicolumn{3}{c}{ N = 180 } \\
\cline { 3 - 6 } & & M & SD & Level \\
\hline A5 & English is useful for me in my future profession. & 4.49 & .67 & Very high \\
A17 & $\begin{array}{l}\text { Being proficient in English can lead to success and achievements in life like } \\
\text { higher salary, promotion, and position. }\end{array}$ & 3.69 & .51 & High \\
A14 & Studying English is important to me because it makes me a knowledgeable & 3.67 & .70 & High \\
& and skillful person which will help me to have a better future. & & & \\
A15 & Other people respect me more if I know English. & 3.65 & .67 & High \\
A8 & Thanks to English I can broaden my cultural horizon. & 3.57 & .60 & High \\
A10 & Knowing English, I can read literary works in the original. & 3.56 & .89 & High \\
A1 & English enables me to communicate with many people. & 3.36 & .34 & High \\
A4 & I often use English to talk to foreigners. & 3.24 & .78 & Average \\
A3 & English helps me to be open-minded and sociable. & 3.23 & .88 & Average \\
A2 & Knowing English, I can read foreign magazines. & 3.06 & .92 & Average \\
A11 & Sometimes I translate English books or instructions on foreign-made & 3.06 & .73 & Average \\
& machines. & & & \\
\hline
\end{tabular}

Note: N: sample; M: mean; SD: standard deviation 
As what can be seen in Table 4, the participants agreed "[they are] determined to study English as best as [they] can to achieve proficiency" (item A7: $\mathrm{M}=3.98, \mathrm{SD}=.61$ ), "studying English is important to [them? because it helps [them] to better understand and appreciate the different cultures and traditions of any country in the world" (item A6: M=3.96, $\mathrm{SD}=.65)$, "Knowing English, [they] can travel all over the world" (item A9: $\mathrm{M}=3.79, \mathrm{SD}=.57$ ), "English can help [them] make friends with people around the world" (item A18: M=3.68, $\mathrm{SD}=.61$ ), "studying English is important to [them] because [they] can understand stories understand stories, conversation, music, movies, and lectures in English" (item A19: $\mathrm{M}=3.66, \mathrm{SD}=.88$ ), "thanks to English [they] can learn more about the life of the English, Americans, Australians etc." (item A12: $\mathrm{M}=3.56, \mathrm{SD}=.71$ ), and "studying English is fun because it helps [them] meet a lot of foreign friends who speak English" (item A13: $\mathrm{M}=3.46, \mathrm{SD}=.89$ ). However, they were neutral about statements: "studying English enables [them] to appreciate other country's arts and literature" (item A16: $\mathrm{M}=3.37, \mathrm{SD}=.77$ ) and "studying English enables [them] to share [their] knowledge with other people and communicate with foreigners better" (item A20: $\mathrm{M}=3.16, \mathrm{SD}=.76$ ).

Table 4

English-Majored Students' Level of Motivation in Terms of Integrative Motivation

\begin{tabular}{|c|c|c|c|c|}
\hline \multirow{2}{*}{ No } & \multirow{2}{*}{ Statement } & \multicolumn{3}{|c|}{$\mathbf{N}=\mathbf{1 8 0}$} \\
\hline & & $\mathbf{M}$ & SD & Level \\
\hline A7 & I am determined to study English as best as I can achieve proficiency. & 3.98 & .61 & High \\
\hline A6 & $\begin{array}{l}\text { Studying English is important to me because it helps me to better understand } \\
\text { and appreciate the different cultures and traditions of any country in the world. }\end{array}$ & 3.96 & .65 & High \\
\hline A9 & Knowing English, I can travel all over the world. & 3.79 & .57 & High \\
\hline A18 & English can help me make friends with people around the world. & 3.68 & .61 & High \\
\hline A19 & $\begin{array}{l}\text { Studying English is important to me because I can understand stories, } \\
\text { conversation, music, movies, and lectures in English. }\end{array}$ & 3.66 & .88 & High \\
\hline A12 & $\begin{array}{l}\text { Thanks to English I can learn more about the life of the English, Americans, } \\
\text { Australians etc. }\end{array}$ & 3.56 & .71 & High \\
\hline A13 & $\begin{array}{l}\text { Studying English is fun because it helps me meet a lot of foreign friends who } \\
\text { speak English. }\end{array}$ & 3.46 & .89 & High \\
\hline A16 & Studying English enables me to appreciate other country's arts and literature. & 3.37 & .77 & Average \\
\hline $\mathrm{A} 20$ & $\begin{array}{l}\text { Studying English enables me to share my knowledge with other people and } \\
\text { communicate with foreigners better. }\end{array}$ & 3.16 & .76 & Average \\
\hline
\end{tabular}

Note: M: mean; SD: Standard deviation

The data from interviews indicate that participants mentioned how they got trouble with their English learning process before getting motivated in learning English. For example:

That was a great time when I traveled to Thailand. People communicated English really well and I realize that English is a benefit tool for everyone to learn another language. From that moment, I felt motivated to learn and improve English and I promised I would study harder when I returned. (S4)

When I studied at primary school or secondary school, learning English was not a pressure for me but when I start to study at university, everything is getting more difficult. I am getting to be trained for the competition but it is not as easy as in secondary school like I used to experience. Because of that, sometimes I feel depressed and disappointed in myself for not trying my best to compete and I really feel unmotivated. (S6)

Besides, interviewees had positive attitudes towards the learning of English before they studied at university, and they easily got the goals or achievements to study well; however, when they were disappointed about the results or they had less chances to perform their abilities, their mood seemed to be unmotivated.

I often feel motivated in learning English when I set a goal in my mind and I have to get it because English was my favorite subject at high school. Even when I study at university right now, I always keep that habit and I believe that this will help me to have good results. However, when 
I am in a sad or bad mood such as I have no reason to study anymore, I will stop and sit alone to find the reason why I have no motivation to learn. (S1)

English is my favorite one. When I studied at high school, I used to think that I had to get achievements such as the award given for province excellent student and for national excellent student when I had a chance because I believe that if I try hard right now, I will get achievements and honors in the future. (S2)

It is obvious that the findings from the interviews are consistent with the findings of the questionnaire. That means the findings revealed that the level of motivation to learn English among the students in BLU was high. Each of them had their own ideas to express motivation but most of them cared about their future careers, achievements or the purposes of learning English. Moreover, they also had the same reason why they felt unmotivated, like not getting the goal they planned in their mind or being pressured when their parents had a belief in them.

4.1.2. English-majored students' use of reading strategies

As shown in Table 5, the mean scores of metacognitive and cognitive strategies are 3.37 and 3.40 out of 5.00 respectively, while the mean score of social/affective strategies is 2.78 . This can be interpreted that research participants sometimes employed metacognitive and social/affective strategies in reading comprehension, but they usually used cognitive strategies in reading comprehension.
Table 5

\section{English-Majored Students' Use of Reading} Strategies

\begin{tabular}{lll}
\hline & \multicolumn{2}{l}{$\mathbf{N = 1 8 0}$} \\
\cline { 2 - 3 } & $\mathbf{M}$ & SD \\
\hline Metacognitive & 3.37 & .85 \\
Cognitive & 3.40 & .75 \\
Social / affective & 2.78 & .92 \\
\hline
\end{tabular}

Note: N: sample; M: mean; SD: standard deviation Specifically, Table 6 describes the results of English-majored students' use of metacognitive strategies. The participants usually used the title to predict contents (item $\mathrm{B} 3: \mathrm{M}=3.82, \mathrm{SD}=.69$ ), determined what to read and skip irrelevant details (item B8: $\mathrm{M}=3.61, \mathrm{SD}=.52$ ), tried to understand the implicit meaning (item B12: $\mathrm{M}=3.58, \mathrm{SD}=.80$ ), and read from the first to the last paragraph (item B18: $\mathrm{M}=3.43, \mathrm{SD}=.85$ ). Nonetheless, they sometimes set goals before reading (item $\mathrm{B} 5: \mathrm{M}=3.39, \mathrm{SD}=.63$ ), imaged or made a picture in their mind in order to understand the text (item B21: $\mathrm{M}=3.37$, $\mathrm{SD}=.55$ ), focused on every word, especially new words (item B6: $\mathrm{M}=3.34, \mathrm{SD}=.70$ ), and paid attention to the beginning and the end of each paragraph (item B20: $\mathrm{M}=3.29, \mathrm{SD}=.91$ ). Additionally, they sometimes considered the text type (item B9: $\mathrm{M}=3.28, \mathrm{SD}=.61$ ), figured out the main idea of each paragraph (item B1: $\mathrm{M}=3.27, \mathrm{SD}=.66$ ), paid attention to linking words (item B4: $\mathrm{M}=3.27, \mathrm{SD}=1.26$ ), predicted what would come next (item B16: $\mathrm{M}=3.13$, $\mathrm{SD}=.80)$ and skimmed the text before reading for details (item B19: $\mathrm{M}=3.06, \mathrm{SD}=.75$ ).

\section{Table 6}

English-Majored Students' Use of Reading Strategies in Terms of Metacognitive Strategies

\begin{tabular}{llcc}
\hline \multirow{2}{*}{ No } & \multicolumn{1}{c}{ Metacognitive strategies } & \multicolumn{1}{c}{$\mathbf{N}=\mathbf{1 8 0}$} \\
\cline { 3 - 4 } & & $\mathbf{M}$ & SD \\
\hline B3 & I use the title to predict contents. & 3.82 & .69 \\
B8 & I determine what to read and skip irrelevant details. & 3.61 & .52 \\
B12 & I try to understand the implicit meaning. & 3.58 & .80 \\
B18 & I read from the first to the last paragraph. & 3.43 & .85 \\
B5 & I set goals before reading. & 3.39 & .63 \\
B21 & I imagine or make a picture in my mind in order to understand the text. & 3.37 & .55 \\
B6 & I focus on every word, especially new words. & 3.34 & .70 \\
B20 & I pay attention to the beginning and the end of each paragraph. & 3.29 & .91 \\
B9 & I consider the text type. & 3.28 & .61 \\
B1 & I figure out the main idea of each paragraph. & 3.27 & .66 \\
B4 & I pay attention to linking words. & 3.27 & .76 \\
B16 & I predict what will come next. & 3.13 & .80 \\
B19 & I skim the text before reading for details. & 3.06 & .75 \\
\hline
\end{tabular}

Note: N: sample; M: mean; SD: standard deviation 
Table 7 shows the results of Englishmajored students' use of cognitive strategies. The participants usually translated each sentence into Vietnamese (item B7: $M=3.55$, $\mathrm{SD}=.96$ ), changed reading speed when they ran out of time (item B15: $\mathrm{M}=3.49, \mathrm{SD}=.85$ ), linked the content to prior knowledge (item B13: $\mathrm{M}=3.48, \mathrm{SD}=.63$ ), guessed words from context clues (item $\mathrm{B} 2$ : $\mathrm{M}=3.44, \mathrm{SD}=.85$ ), and skipped sentences if they were not suitable for the answer (item B11: M=3.44, SD=.88). However, they sometimes guessed words from prior knowledge (item B14: $\mathrm{M}=3.39, \mathrm{SD}=.65$ ), they broke words into parts (item B17: $\mathrm{M}=3.30$, $\mathrm{SD}=.72$ ) and tried to understand without translating (item $\mathrm{B} 10$ : $\mathrm{M}=3.14, \mathrm{SD}=.63$ ).

\section{Table 7}

English-Majored Students' Use of Reading Strategies in Terms of Cognitive Strategies

\begin{tabular}{|c|c|c|c|}
\hline \multirow{2}{*}{ No } & \multirow{2}{*}{ Cognitive strategies } & \multicolumn{2}{|c|}{$\mathbf{N}=180$} \\
\hline & & $\mathbf{M}$ & SD \\
\hline B7 & $\begin{array}{l}\text { I translate each sentence into } \\
\text { Vietnamese. }\end{array}$ & 3.55 & .96 \\
\hline B15 & $\begin{array}{l}\text { I change reading speed when I } \\
\text { run out of time. }\end{array}$ & 3.49 & .85 \\
\hline B13 & $\begin{array}{l}\text { I link the content to prior } \\
\text { knowledge. }\end{array}$ & 3.48 & .63 \\
\hline B2 & $\begin{array}{l}\text { I guess words from context } \\
\text { clues. }\end{array}$ & 3.44 & .85 \\
\hline B11 & $\begin{array}{l}\text { I skip sentences if they are not } \\
\text { suitable for the answer }\end{array}$ & 3.44 & .88 \\
\hline B14 & $\begin{array}{l}\text { I guess words from prior } \\
\text { knowledge. }\end{array}$ & 3.39 & .65 \\
\hline B17 & I break words into parts. & 3.30 & .72 \\
\hline B10 & $\begin{array}{l}\text { I try to understand without } \\
\text { translating. }\end{array}$ & 3.14 & .63 \\
\hline
\end{tabular}

Note: N: sample; M: mean; SD: standard deviation

The third reading strategy type included four social/affective strategies as seen in Table 8 . The participants sometimes worked together with their classmates to solve the questions in the reading texts (item $\mathrm{B} 22: \mathrm{M}=3.13, \mathrm{SD}=.81$ ), asked the teacher, classmates or friends for help (item B23: $\mathrm{M}=2.87, \mathrm{SD}=.73$ ), made critical comments or evaluate the content of the text and then shared with their friends (item B25: $\mathrm{M}=2.59, \mathrm{SD}=.76$ ) and discussed the problems and difficulties with teachers or friends (item B24: $\mathrm{M}=2.51, \mathrm{SD}=.62$ ).

\section{Table 8}

English-Majored Students' Use of Reading Strategies in Terms of Social / Affective Strategies

\begin{tabular}{llcc}
\hline \multirow{2}{*}{ No } & \multicolumn{1}{c}{ Cognitive strategies } & \multicolumn{2}{c}{$\mathbf{N}=\mathbf{1 8 0}$} \\
\cline { 2 - 4 } B22 & $\begin{array}{l}\text { I work together with my } \\
\text { classmates to solve the questions } \\
\text { in the reading texts. }\end{array}$ & 3.13 & .81 \\
B23 & $\begin{array}{l}\text { I ask the teachers, classmates or } \\
\text { friends for help. }\end{array}$ & 2.87 & .73 \\
B25 & $\begin{array}{l}\text { I make critical comments or } \\
\text { evaluate the content of the text } \\
\text { and then share with my friends. }\end{array}$ & 2.59 & .76 \\
B24 & $\begin{array}{l}\text { I discuss the problems and } \\
\text { difficulties with teachers or } \\
\text { friends. }\end{array}$ & 2.51 & .62 \\
\hline
\end{tabular}

Note: N: sample; M: mean; SD: standard deviation

In order to confirm the findings from the questionnaire, the qualitative data helped give a broad view on the students' reading comprehension strategies. The idea that some parts of a text may be ignored or skipped is strange to some students, but efficient reading, and specifically the techniques of scanning and skimming, requires it. During the interview, interviewees agreed that using a scanning method was the best way to do a reading test.

About reading strategies, I often use scanning. I realize that this is an effective method because when I use scanning, I can understand the main idea in the passage and then I can guess the answer quickly in each question. (S4)

When facing the reading test, I usually use scanning the whole paragraph and then I look at the questions to find the key words. After that, I come back to the paragraph to find the key word and then choose the answer. (S5)

4.1.3. Relationship between Englishmajored students' motivation and their reading strategies

As indicated in Table 9, the results of the correlational analysis reveal that participants' motivation was correlated with their reading strategies. To be more specific, participants' instrument motivation and integrative motivation were positively correlated with their metacognitive $(\mathrm{r}=.27 ; \mathrm{p}=.000 / \mathrm{r}=.19 ; \mathrm{p}=.000)$ and cognitive strategies $(\mathrm{r}=.41 ; \mathrm{p}=.000 / \mathrm{r}=.50 ; \mathrm{p}=.000)$ but negatively correlated with their social / 
affective strategies $(\mathrm{r}=-.30 ; \mathrm{p}=.000 / \mathrm{r}=-.22$; $\mathrm{p}=.000$ ). It can be understood that the more participants were instrumentally and integratively motivated in English language learning, the more they used metacognitive and cognitive reading strategies; nevertheless, the higher participants' level of instrumental and integrative motivation in
English language learning was, the less they employed social / affective reading strategies. To put it simply, participants' motivation in English language learning affected their cognitive and metacognitive reading strategies but social / affective reading strategies.

Table 9

Relationship Between the English-Majored Students' Motivation and Their Reading Strategies

\begin{tabular}{lllll}
\hline & & $\begin{array}{c}\text { Metacognitive } \\
\text { strategies }\end{array}$ & $\begin{array}{c}\text { Cognitive } \\
\text { strategies }\end{array}$ & $\begin{array}{c}\text { Social/Affective } \\
\text { strategies }\end{array}$ \\
\hline Instrument motivation & Pearson Correlation & .27 & .41 & -.30 \\
& Sig. (2-tailed) & .00 & .00 & .00 \\
Integrative motivation & Pearson Correlation & .19 & .50 & -.22 \\
& Sig. (2-tailed) & $.01 * *$ & $.00^{* *}$ & $.00^{* *}$ \\
\hline
\end{tabular}

$* * \mathrm{p}<=.01 ; * \mathrm{p}<=.05$

\subsection{Discussion}

This study showed that participants had a high level of motivation in English language learning, and they agreed that integrative motivation was more important than instrument motivation in learning English. A possible explanation for this might be that students could overcome the common difficulties such as lack of opportunity to use English in their daily lives; being passive learners; being too shy to use English with classmates; and lack of responsibility for their own learning. The finding is supported by ideas of researchers such as Weiler (2005), Ngo (2015) and Nguyen (2019) who have asserted that students have a different vision of the world; they also become open minded and sociable because of their understanding and knowledge from traveling and finding the new world in the English contexts.

Furthermore, the participants used metacognitive strategies more frequently than cognitive strategies and social/affective strategies. This result may be explained that participants may practice doing reading comprehension texts when they self-study English, especially using the prediction, setting the goal, scanning or skimming the text before answering the questions. Another less frequently used was cognitive strategies. Even though the participants admitted that they often translated each sentence into Vietnamese and even when they ran out of time, they changed the speed to find the answers as quickly as they could or they try to link the content that they have known before into the prior knowledge in order to look for the key word in each sentence, they still could become accustomed to it and they use less the other strategies like breaking words into parts, guessing words from previous knowledge or even they could do the answers without translating. Additionally, the participants did not frequently employ social/affective strategies. The social/affective strategies represented the cooperation with the classmates like working together with classmates to solve the questions in the reading texts or discussing the problems and difficulties with teachers or friends seemed like not highly being used. It may be due to limited time to do the reading texts, so doing in groups is not as effective as doing individual. Moreover, Traxler and his colleagues' study (2012) mentioned that doing reading comprehension text was an individual working and they concluded that when the students did the text, it depended on reading speed more than working memory capacity. Therefore, that might be the reason why the participants had a craving for doing reading comprehension text individually. They admitted that they wanted to reach the high scores so they had to do the text themselves.

Additionally, it was found out that metacognitive and cognitive strategies had a positive and correlation with instrument and integrative motivation. It can be explained that when the students get highly motivated to learn English, they may fancy on using metacognitive and cognitive strategies. Moreover, these strategies might be easy for them to use effectively and perform well in the reading comprehension texts. Although there was a negative correlation between social/affective strategies and motivation, it still had a 
relationship together. Due to this finding, the reason can be proved that the participants often practice the reading texts themselves and they rarely need help or cooperate with their classmates if they have trouble in reading texts. This strategy seemed to be used less than the other strategies. This result was in alignment with that of Guo and Zhang's (2020) study which has revealed that students' motivation in English language learning influences their cognitive and metacognitive reading strategies positively.

\section{Conclusion}

This study unravels that English-majored students were motivated in English language learning, and they preferred metacognitive strategies in reading comprehension to cognitive and social/affective ones. What is more, the more English-majored students were motivated in English language learning, the more they used metacognitive and cognitive strategies, but the less they utilized social/affective strategies.

Several implications are drawn based on the findings. First, the teaching of reading should include reading materials which are relevant to students' life and interest so that they are motivated, which can entail the use of reading strategies in reading comprehension. Secondly, different pairwork and groupwork activities should be introduced to students in learning reading comprehension so that they can enhance the use of social/affective strategies as pairwork and groupwork activities can compensate for students' social/affective strategies (e.g., Cogmen \& Saracaloglu, 2009; Dao, 2010). Students can learn from one another to solve the reading questions and share their reading strategies with one another. Thirdly, teachers should encourage students to share their reading experience and difficulties in reading comprehension, so good reading experience can be disseminated and difficulties in reading comprehension can be solved. Fourthly, a supportive and comfortable atmosphere in the classroom should be designed. Teachers should create the atmosphere in class in order to encourage students and avoid taking risk of mistakes as a part of learning. Only that way can boost students' comfort without worrying about being criticized or embarrassed, which may affect their involvement in activities in the classroom. Fifthly, students should practice reading both at school and at home as the more they practice reading, the better their reading skills will be. Besides, they should determine reading strategies which are suitable for them and their reading purposes in order to use them effectively.

This study still bears some limitations. This study involved only six participants in taking part in interviews, and only freshmen participated in this study. It is recommended that participants from different levels of academic year should get involved in the study so that the results can be generalized.

\section{References}

Al-Issa, A. (2006). Schema theory and L2 reading comprehension: Implications for teaching. Journal of College Teaching \& Learning, 3(7). https://doi.org/10.19030/tlc.v3i7.1700

Anderson, N. J. (2003). Scrolling, clicking, and reading English: Online reading strategies in a second/foreign language. The Reading Matrix, 3(3), 1-33.

Brown, H. D. (2001). Teaching by Principles: An interactive approach to language pedagogy (2nd ed.). Pearson

Chambers, G. N. (1999). Motivating Language Learners. Multilingual Matters.

Cogmen, S., \& Saracaloglu, A. S. (2009). Students' usage of reading strategies in the faculty of education. Procedia - Social and Behavioral Sciences, 1(1), 248251. https://doi.org/10.1016/j.sbspro.2009.01.045

Crookes, G., \& Schmidt, R. (1991). Motivation: Reopening the research agenda. Language Learning, 41(4), 469-512. https://doi.org/10.1111/j.14671770.1991.tb00690.x

Dao, T. M. H. (2010). The relationship between first-year Nghe An College students' motivation to read and their use of reading strategies [Master's thesis, Vietnam National University, Hanoi]. VNU Repository. http://repository.vnu.edu.vn/handle/VNU_123/40767

Ellis, R. (1994). The study of second language acquisition. Oxford University Press.

Finegan, E. (1999). Language: Its structure and use (3rd ed.). Harcourt Brace College Publishers.

Gardner, R. C. (1985). Social psychology and second language learning: The role of attitudes and motivations. Edward Arnold.

Goodman, K. S. (1988). The reading process. In P. L. Carrell, J. Devine \& D. E. Eskey (Eds.), Interactive Approaches to Second Language Reading (pp. 11-21). Cambridge University Press.

Guo, L., \& Zhang, X. (2020). Cognitive and metacognitive reading strategies training in EFL reading. Advances in Social Science, Education and Humanities Research, 428, pp. 110-114. https://doi.org/10.2991/assehr.k.200401.028 
Hong-Nam, K., \& Leavell, A. G. (2006). Language learning strategies of ESL in an intensive English learning context. System, 34(3), 399-415. https://doi.org/10.1016/j.system.2006.02.002

Luc, T. M. B. (2011). Developing motivation in learning English reading skill of the students at Thieu Hoa high school, Thanh Hoa province [Master's thesis, Vietnam National University, Hanoi]. VNU Repository. http://repository.vnu.edu.vn/handle/VNU_123/40648

Mart, C. T. (2012). Developing speaking skills through reading. International Journal of English Linguistics, 2(6), 91-96. https://doi.org/10.5539/ijel.v2n6p91

Ngo, H. T. (2015). An investigation into students' motivation to learn English in higher education in Vietnam [Doctoral dissertation, Queensland University of Technology]. https://eprints.qut.edu.au/84470/

Nguyen, C. H. (2019). Motivation in learning English language: A case study at Vietnam National University, Hanoi. European Journal of Educational Sciences, (1), 49-65.

O'Malley, J. M., \& Chamot, A. U. (1990). Learning strategies in second language acquisition. Cambridge University Press.

Pardo, L. S. (2004). What every teacher needs to know about comprehension. The Reading Teacher, 58(3), 272-280. https://doi.org/10.1598/rt.58.3.5

Richards, R., \& Thomas, G. (1987). Being an effective reading teacher. Harper and Row Publishers.

Sheorey, R., \& Mokhtari, K. (2001). Differences in the metacognitive awareness of reading strategies among native and non-native readers. System, 29(4), 431-449. https://doi.org/10.1016/s0346-251x(01)00039-2

Tran, Q. T., \& Duong, M. T. (2018). The difficulties in ESP reading comprehension encountered by English-majored students. VNU Journal of Foreign Studies, 34(2), 151161. https://doi.org/10.25073/2525-2445/vnufs.4253

Tran, Q. T., \& Tran, T. S. (2018). Factors affecting EFL reading comprehensibility of Vietnamese secondary school students: A Case Study. In Faculty of Foreign Languages (Eds.), Proceedings of the International conference: Language Teaching and Learning Today 2018 (pp. 289-302). Vietnam National University, Ho Chi Minh Press.

Traxler, M. J., Long, D. L., Tooley, K. M., \& Johns, C. L. (2012). Individual differences in eye-movements during reading: Working memory and speed-of-processing effects. Journal of Eye Movement Research, 5(1), 1-16. https://doi.org/10.16910/jemr.5.1.5

Ur, P. (1996) A course in language teaching: Practice and theory. Cambridge University Press.

Vallerand, R. J., Pelletier, L. G., Blais, M. R., Briere, N. M., Senecal, C., \& Vallieres, E. F. (1992). The academic motivation Scale: A measure of intrinsic, extrinsic, and amotivation in education. Educational and Psychological Measurement, 53, 1003-1017.

Weiler, A. (2005). Information-seeking behavior in Generation Y students: Motivation, critical thinking, and learning theory. The Journal of Academic Librarianship, 31(1), 46-53.

Wharton, G. (2000). Language learning strategy use of bilingual foreign language learners in Singapore. Language Learning, 50(2), 203-243.

William, M., \& Burden, R. L. (1997). Psychology for Language Teachers. Cambridge University Press.

Yunus, M. M., \& Abdullah, N. R. K. R. B. (2011). Motivation and attitudes for learning English among year six students in primary rural school. Procedia Social and Behavioral Sciences, 15, 2631-2636. https://doi.org/10.1016/j.sbspro.2011.04.160

\title{
ĐộNG CO’ HỌC TIẾNG ANH VÀ CHIẾN LƯỢC ĐỌC HIỂU CỦA SINH VIÊN CHUYÊN NGÀNH TIẾNG ANH
}

\author{
Trần Quốc Thao ${ }^{1}$, Nguyễn Hoàng Châu Long ${ }^{2}$ \\ 1. Đại học Công nghệ Tp. Hồ Chi Minh \\ 475A Điện Biên Phủ, P. 25, Q. Bình Thạnh, Tp. Hồ Chí Minh, Việt Nam \\ 2. Truờng THPT Chuyên Phan Ngọc Hiển \\ 74 Phan Đình Phùng, P. 2, Tp. Cà Mau, Cà Mau, Việt Nam
}

Tóm tắt: Kỹ năng đọc đóng một vai trò quan trọng trong quá trình học ngôn ngữ thứ hai/ngoại ngữ vì nó giúp cho việc phát triển người học tự chủ. Ngoài ra, việc sử dụng chiến lược đọc của người học tiếng Anh là ngôn ngữ thứ hai có thể bị ảnh hưởng bởi động cơ học tập của họ, và có thể tác động đến mức độ sử dụng chiến lược đọc cao hay thấp. Do đó, nghiên cứu này tìm hiểu động cơ học tập và việc sử dụng chiến lược đọc hiểu của sinh viên chuyên ngành tiếng Anh tại một trường đại học ở tỉnh Bạc Liêu. Một bảng câu hỏi được sử dụng để lấy dữ liệu từ 180 sinh viên năm thứ nhất chuyên ngành tiếng Anh, và sáu sinh viên tham gia trả lời phỏng vấn bán cấu trúc. Kết quả cho thấy sinh viên chuyên ngành tiếng Anh có động cơ học tập cao và họ sử dụng chiến lược siêu nhận thức tốt hơn so với chiến lược nhận thức và chiến lược xã hội/tình cảm. Nghiên cứu còn cho thấy động cơ học tiếng Anh của sinh viên càng cao thì họ sử dụng chiến lược siêu nhận thức và chiến lược nhận thức càng cao.

Tù khóa: động cơ, chiến lược đọc, đọc hiểu, sinh viên chuyên ngành tiếng Anh, tiếng Anh 